\title{
Cyclic AMP-Dependent Phosphorylation of a Neuronal Acetylcholine Receptor $\alpha$-Type Subunit
}

\author{
Sukumar Vijayaraghavan, Herbert A. Schmid, Stanley W. Halvorsen, and Darwin K. Berg \\ Department of Biology, University of California at San Diego, La Jolla, California 92093
}

\begin{abstract}
Chick ciliary ganglion neurons have nicotinic acetylcholine receptors (AChRs) that mediate synaptic transmission through the ganglion. A cAMP-dependent process has previously been shown to enhance the $A C h$ response of the neurons 2- to 3-fold without requiring the synthesis of new receptors. We show here that the receptors can be phosphorylated in situ by a cAMP-dependent process. The phosphorylation occurs predominantly on components of 50 and $58 \mathrm{kDa}$. Both derive from putative ligand-binding $\alpha 3$ subunits, with the smaller phosphorylated species probably representing a degradation product of the larger. The increase in receptor phosphorylation caused by incubating the neurons with a CAMP analog parallels the increase observed in the $A C h$ response, with respect to both time course and relative extent. The phosphorylation of ciliary ganglion AChRs differs from that reported for electric organ AChRs, which occurs primarily on the non-ligand-binding $\gamma$ and $\delta$ subunits and increases the rate of agonist-induced receptor desensitization.
\end{abstract}

Second messengers have been widely observed to modulate the function of ion channels in the nervous system (for reviews, see Kaczmarek and Levitan, 1987; Levitan, 1988). For ligand-gated channels, the modulation usually involves a decrease in channel function. CAMP analogs reversibly decrease the ACh response of rat myotubes by increasing the rate of agonist-induced receptor desensitization (Albuquerque et al., 1986; Middleton et al., 1986, 1988). Phorbol esters decrease the ACh response of chick sympathetic neurons in a similar manner (Downing and Role, 1987). Phorbol esters also reversibly decrease the ACh response of chick myotubes (Eusebi et al., 1985), and cAMP analogs decrease the function of GABA receptors in rat brain synaptosomes (Heuschneider and Schwartz, 1989).

ACh receptors (AChRs) on chick ciliary ganglion neurons provide an exception to the pattern of second-messenger modulation for ligand-gated ion channels. While cAMP analogs have

\footnotetext{
Received Mar. 15, 1990; revised May 15, 1990; accepted May 17, 1990.

We thank Drs. Ralf Schoepfer, Paul Whiting, and Jon Lindstrom (The Salk Institute) for the antiserum to the $\mathrm{AChR} \alpha 3$ fusion protein, and we thank Dr. Farooq Azam (Scripps Institute of Oceanography) for help with the luciferase assays. Drs. John C. Lawrence, Jr. and John Merlie (Washington Univ., St. Louis) generously provided purified phosphorylase $b$ and phosphorylase kinase. Dannielle Pellegrin and Susan Tsunoda prepared the cell cultures. Grant support was provided by NIH Grants RO1 NS12601 and PO1 NS25916 and by grants from the Muscular Dystrophy Association and the American Heart Association, with funds contributed in part by the California Heart Association. S.V. is an MDA Postdoctoral Fellow.

Correspondence should be addressed to Darwin K. Berg, Department of Biology, B-022, University of California at San Diego, La Jolla, CA 92093.

Copyright (C) 1990 Society for Neuroscience $0270-6474 / 90 / 103255-08 \$ 03.00 / 0$
}

a small effect on agonist-induced desensitization, they cause a much larger increase in the overall ACh response of the cells. The increase does not require de novo synthesis of new receptors (Margiotta et al., 1987a; Margiotta and Gurantz, 1989). Moreover, the increased response does not appear to involve a change in the total number of AChRs on the cell surface or a change in the properties of functional receptors. These observations have led to the novel hypothesis that a cAMP-dependent process converts AChRs from a "silent" state on the neurons to a "functionally available" one (Margiotta et al., 1987a). In support of the hypothesis, it was found that the total number of AChRs on the cells substantially exceeds the number of functional AChRs detected electrophysiologically (Margiotta et al., 1987b). The mechanism by which cAMP enhances the function of chick ciliary ganglion AChRs is unknown. A report that cAMP analogs also increase the nicotinic response of bovine adrenal chromattin cells in culture (Higgins and Berg, 1988) was incorrect because of procedural errors in the assays used for receptor function (see McEachern et al., 1989, Note Added in Proof).

Altering the state of protein phosphorylation is a common mechanism by which second messengers regulate protein function. This has been clearly shown for one ligand-gated ion channel, the AChR of Torpedo electric organs. The receptors are pentameric proteins with 4 types of subunits $\left(\alpha_{2}, \beta, \gamma\right.$, and $\left.\delta\right)$. Incubating the purified receptor with cAMP-dependent protein kinase and ATP produces rapid phosphorylation of the $\gamma$ and $\delta$ subunits. Reconstitution experiments with phospholipid vesicles demonstrates that the phosphorylation produces an increase in the rate of agonist-induced receptor desensitization (Huganir et al., 1986). Phosphorylation of the receptor by tyrosine kinase has a similar effect on receptor function (Hopfield et al., 1988). Skeletal muscle AChRs may be regulated in the same way: cAMP analogs increase agonist-induced AChR desensitization as described above and stimulate rapid phosphorylation of the receptors in situ on $\delta$ subunits (Miles et al., 1987; Smith et al., 1987).

Phosphorylation of neuronal AChRs has not been examined. Recently, AChRs have been immunopurified from chick ciliary ganglia and shown to contain components with $M_{\mathrm{r}} \mathrm{s}$ of 49, 52, and $60 \mathrm{kDa}$ (Halvorsen and Berg, 1990). The largest species appears to be a neuronal $\mathrm{AChR} \alpha 3$ gene product. $\alpha 3$ transcripts are relatively abundant in the ganglion (Boyd et al., 1988), and a component of similar size to the large species can be affinity labeled with neuronal bungarotoxin, suggesting that it carries the ligand-binding site as expected for $\alpha$ subunits (Halvorsen and Berg, 1987). More compelling evidence for the $60-\mathrm{kDa}$ component being an $\alpha 3$ gene product comes from the observation that an antiserum raised against an $\alpha 3$ fusion protein (Schoepfer et el., 1989) selectively immunoprecipitates the 60- 
$\mathrm{kDa}$ species (Halvorsen and Berg, 1990). The 49-kDa component selectively crossreacts on immunoblots with 4 monoclonal antibodies that recognize a component of similar size in AChR preparations from the chicken brain. The $52-\mathrm{kDa}$ component is a novel species not previously identified with neuronal AChRs. If all 3 types of components are AChR subunits, as seems likely, it remains to be determined whether they are present in the same receptor molecule. Some evidence suggests that the components may comprise 2 distinct receptor subtypes, one made up of 49- and $60-\mathrm{kDa}$ subunits and the other made up of 52and 60-kDa subunits (Halvorsen and Berg, 1990).

We have examined cAMP-dependent phosphorylation of chick ciliary ganglion AChRs in situ by incubating the neurons in culture with ${ }^{32} \mathrm{P}$-orthophosphate in the presence and absence of cAMP analogs, then immunopurifying the receptors and determining their extent of labeling. We show here that the receptors become phosphorylated in a cAMP-dependent manner on putative $\alpha 3$ subunits. The extent of phosphorylation is substantial, reaching a level of $0.5 \mathrm{~mol}$ phosphate per mol receptor (in addition to the basal level of $0.3 \mathrm{~mol}$ phosphate per mol receptor) in $6 \mathrm{hr}$, and occurs with a time course comparable to that observed for the cAMP-dependent enhancement of the neuronal ACh response.

\section{Materials and Methods}

Purification of Radiolabeled AChRs. Chick ciliary ganglion neurons from 8-day-old embryos were grown in cell culture (40 dissociated ganglia per $60 \mathrm{~mm}$ dish) for 6-7 days as previously described (Nishi and Berg, 1981). To obtain ${ }^{32} \mathrm{P}$-labeled AChRs, the culture medium was replaced with $4 \mathrm{ml}$ phosphate-free Eagle minimal essential medium containing $3 \mathrm{mg} / \mathrm{ml} \mathrm{BSA}$ and $2.5 \mathrm{mCi}{ }^{32} \mathrm{P}$-orthophosphate. After $6 \mathrm{hr}$ incubation with or without $2 \mathrm{~mm}$ 8-bromo-cAMP (8-Br-cAMP) and $1 \mathrm{~mm} 3$-isobutyl-1-methylxanthine (IBMX), unless otherwise indicated, the labeling medium was removed, and the cells were scraped into $300 \mu \mathrm{lex}-$ traction buffer composed of $5 \mathrm{mM} \mathrm{NaPO}$ (pH, 7.4), $1 \%$ Triton X-100, $1 \mathrm{~mm}$ ATP, $100 \mathrm{~mm} \mathrm{NaF}, 10 \mathrm{~mm} \mathrm{Na}_{4} \mathrm{P}_{2} \mathrm{O}_{7}, 25 \mu \mathrm{M}$ ammonium molybdate, and protease inhibitors $(1 \mathrm{mM}$ EDTA, $1 \mathrm{mM}$ EGTA, $1 \mathrm{~mm}$ phenylmethylsulfonyl fluoride, $1 \mu \mathrm{g} / \mathrm{ml}$ phosphorhamidon, $10 \mu \mathrm{g} / \mathrm{ml}$ pepstatin, $10 \mu \mathrm{g} / \mathrm{ml}$ leupeptin, $200 \mu \mathrm{g} / \mathrm{ml}$ iodoacetamide, $200 \mu \mathrm{g} / \mathrm{ml}$ benzamidine, and $100 \mu \mathrm{g} / \mathrm{ml}$ soybean trypsin inhibitor). The insoluble material was removed by centrifugation, and the detergent extract was incubated twice with $50 \mu \mathrm{l}$ rat IgG Sepharose to remove material that nonspecifically absorbed to the resin. The recovered supernatant fraction was then incubated with $10 \mu \mathrm{l}$ monoclonal antibody (mAb) 35 Sepharose for $90 \mathrm{~min}$ at room temperature on an orbital shaker to absorb AChRs. The procedure depleted $90 \%$ of the AChRs from the extract as determined by ${ }^{125} \mathrm{I}-\mathrm{mAb}-35$ binding. The resin was then washed 3 times with $1-\mathrm{ml}$ aliquots of extraction buffer containing $1 \mathrm{M} \mathrm{NaCl}$ and $0.1 \%$ Triton X-100 (instead of $1 \%$ ), then 3 times with extraction buffer containing $1 \%$ Triton $X-100$. AChRs were eluted from the immunoaffinity matrix with $30 \mu 1$ citrate buffer (100 mm sodium citrate; pH, 3.0), neutralized by adding $10 \mu \mathrm{l} 1.5 \mathrm{M}$ Tris- $\mathrm{HCl}(\mathrm{pH}, 8.8)$ and diluted in $3 \mathrm{X}$ SDS sample buffer to a vol of $60 \mu \mathrm{l}$ for analysis by SDS-PAGE.

For ${ }^{125}$ I-labeled AChRs, cells were treated as described above, except that unlabeled phosphate was used to replace the ${ }^{32} \mathrm{P}$-orthophosphate. AChRs were then radioiodinated by the chloramine $T$ method and immunopurified with 2 rounds of absorption to $\mathrm{mAb}-35$ Sepharose using the $\mathrm{MgCl}_{2}$ elution procedure previously described (Halvorsen and Berg, 1990). In some experiments, ${ }^{32} \mathrm{P}$-labeled AChR was immunopurified in parallel, using 2 rounds of absorption with $\mathrm{mAb}-35$ Sepharose.

AChR subunits were separated by SDS-PAGE. Usually, autoradiography was used to locate labeled components. The corresponding regions of the dried gel were then excised and analyzed by liquid scintillation counting for ${ }^{32} \mathrm{P}$ radioactivity or by gamma counting for ${ }^{125} \mathrm{I}$ radioactivity. The results were corrected by subtracting nonspecific radioactivity observed for samples lacking AChRs that were analyzed in parallel on adjacent gel lanes. The "receptor-free" samples were generated by using free mAb 35 to prevent absorption of AChRs during the immunoaffinity step (see Fig. 1, lanes 3 and 6). In some experiments, the isolated subunits were eluted from hydrated gel slices as previously described (Halvorsen and Berg, 1990).

Immunoprecipitation with anti- $\alpha 3$ antiserum. ${ }^{32} \mathrm{P}$ - and ${ }^{125} \mathrm{I}$-labeled AChRs were prepared, purified, and submitted to SDS-PAGE to separate subunits. For the ${ }^{32} \mathrm{P}$-labeled receptor, 2 adjacent gel slices were cut from the 49-53-kDa region of the gel, and 2 were cut from the 56$60-\mathrm{kDa}$ region. Each of the 4 resulting slices was eluted separately overnight into $100 \mu 175 \mathrm{mM} \mathrm{NaPO}_{4}(\mathrm{pH}, 7.5)$ containing $75 \mathrm{mM} \mathrm{NaCl}$ and $0.5 \%$ Triton $\mathrm{X}-100$. The liquid phase was recovered in each case and incubated with Staphylococcus aureus cells coated with the anti- $\alpha 3$ antiserum as previously described (Schoepfer et al., 1989; Halvorsen and Berg, 1990). The cells were then collected by centrifugation, rinsed once, and extracted with SDS sample buffer. For ${ }^{125}$ I-labeled receptors, the 49-53-kDa region of the gel was eluted as one sample and the 56-60$\mathrm{kDa}$ region was eluted as a second sample. Each eluate was subjected to 3 sequential immunoprecipitations with anti- $\alpha 3$ antiserum. Material remaining in solution was precipitated with cold acetone and solubilized in SDS sample buffer. All fractions were examined by SDS-PAGE autoradiography.

Peptide mapping. Peptide mapping of ${ }^{125}$ I-labeled material after partial proteolysis was performed by a modification of the method of Cleveland et al. (1977). Immunoprecipitations were carried out as described above, and the absorbed material was eluted into $50 \mu 125 \mathrm{~mm}$ Tris- $\mathrm{HCl}(\mathrm{pH}$, 6.8 ) containing $0.5 \%$ SDS, $10 \%$ glycerol, and 1 mM EDTA. Material remaining in solution after immunoprecipitation was precipitated with cold acetone as described above and redissolved in $50 \mu 1$ of the same solution. The samples were subjected to partial proteolysis by adding either $10 \mu \mathrm{l} 20 \mu \mathrm{g} / \mathrm{ml}$ papain or $5 \mu \mathrm{l} 1 \mathrm{mg} / \mathrm{ml}$ Staphylococcus V8 protease for $30 \mathrm{~min}$ at $37^{\circ} \mathrm{C}$, then stopping the reaction by adding $5 \mu \mathrm{l}$ of a solution containing $6.6 \%$ SDS and $33 \% \beta$-mercaptoethanol. The samples were analyzed by SDS-PAGE autoradiography using $15 \%$ acrylamide gels.

$\gamma_{-32} \mathrm{P}-A T P$-specific activity. The amount of ATP in cell cultures was determined by the luciferin-luciferase method of Karl and Holm-Hansen (1976). Cell cultures were incubated with or without 8-Br-cAMP for $6 \mathrm{hr}$ under labeling conditions (substituting unlabeled phosphate for ${ }^{32} \mathrm{P}$-orthophosphate), then scraped in $0.2 \mathrm{ml} 0.5 \mathrm{M} \mathrm{HClO}_{4}$. The insoluble material was removed by centrifugation, and the extract was neutralized using a saturated solution of $\mathrm{KHCO}_{3} . \mathrm{KClO}_{4}$ precipitate was removed by centrifugation, and the extract was diluted to $2 \mathrm{ml}$ with $25 \mathrm{~mm}$ Tris$\mathrm{HCl}(\mathrm{pH}, 7.7)$. An aliquot $(0.2 \mathrm{ml})$ was added to $0.5 \mathrm{ml}$ firefly lantern extract ( $50 \mathrm{mg}$ in $35 \mathrm{ml}$ water containing $1 \mathrm{mg}$ synthetic luciferin). The emitted light was measured using an ATP photometer, calibrated with standard ATP samples $(1-100 \mathrm{ng} / \mathrm{ml})$ prepared in the same manner.

To determine the specific activity of the $\gamma^{-32} \mathrm{P}$-ATP pool, perchloric acid extracts were prepared from ${ }^{32} \mathrm{P}$-labeled cultures and neutralized with $\mathrm{KHCO}_{3}$ as described above. To $0.1 \mathrm{ml}$ sample was added $10 \mu \mathrm{l} 1$ mM ATP, and the specific activity was determined by the phosphorylase method of England and Walsh (1976). Unlabeled ATP was added to the reaction to drive it to completion. A standard curve was generated using ATP samples diluted from a stock of $\gamma-{ }^{32} \mathrm{P}-\mathrm{ATP}$. Knowing the amount of unlabeled ATP added to the extracts and the amount of endogenous ATP from the luciferin-luciferase determinations, it was possible to calculate the specific activity of the cellular $\gamma-{ }^{32} \mathrm{P}$-ATP pool.

Intracellular recording. ACh responses from chick ciliary ganglion neurons in culture were obtained using intracellular recording techniques as previously described (Smith et al., 1983; McEachern et al., 1985). Briefly, ACh was applied to a neuronal soma by pressure ejection from a nearby micropipette while recordings from the neuron were made with an intracellular microelectrode. Constant current pulses were passed through the electrode before, during, and after application of ACh to calculate the change in membrane conductance caused by the agonist. ACh concentrations of 10-30 $\mu \mathrm{M}$ were routinely used. The cultures were prepared with 1-2 ganglion equivalents of cells per $35-\mathrm{mm}$ dish and were incubated with $2 \mathrm{mM} 8-\mathrm{Br}$-cAMP and $1 \mathrm{mM}$ IBMX for the indicated time prior to testing as previously described (Margiotta et al., 1987a).

Materials. White Leghorn embryonated chick eggs were obtained locally and maintained at $39^{\circ} \mathrm{C}$ in a humidified incubator. Culture media components were obtained as previously described (Nishi and Berg, 1981). $\mathrm{mAb} 35$ was purified and radioiodinated to specific activities of $2-3 \times 10^{18} \mathrm{cpm} / \mathrm{mol}$ and was used to measure solubilized AChRs with the aid of small DEAE-cellulose columns as previously described (Smith et al., 1985). mAb-35 Sepharose was prepared as previously described (Whiting and Lindstrom, 1986). The antiserum against an $\alpha 3$ fusion 
protein was generated in rabbits and generously supplied by Drs. Ralf Schoepfer and Jon Lindstrom (The Salk Institute). The enzymes phosphorylase $\mathrm{b}$ and phosphorylase kinase were purified and generously provided by Drs. John C. Lawrence, Jr. and John Merlie (Washington University, St. Louis). Luciferin-luciferase reagents, nucleotides, forskolin, and IBMX were purchased from Sigma. $\gamma{ }^{-32} \mathrm{P}-\mathrm{ATP}$ at $3000 \mathrm{Ci} /$ mmol was purchased from NEN; ${ }^{32} \mathrm{P}$-orthophosphate at $274 \mathrm{mCi} / \mathrm{ml}$ was purchased from ICN. Papain and Staphylococcus V8 protease were from Boehringer Mannheim.

\section{Results}

\section{cAMP-dependent phosphorylation of AChRs}

cAMP-dependent phosphorylation of neuronal AChRs was examined in situ by incubating chick ciliary ganglion neurons in cell culture with ${ }^{32} \mathrm{P}$-orthophosphate in the presence or absence of a cAMP analog. A 6-hr time period was chosen for the incubation because previous experiments indicated that this was sufficient for cAMP analogs to achieve a maximal enhancement of neuronal ACh sensitivity in cell culture (Margiotta et al., 1987a). Culture homogenates were then prepared, and AChRs were rapidly isolated by 1 round of immunoaffinity absorption with the anti-AChR monoclonal antibody $\mathrm{mAb} 35$ coupled to Sepharose.

Analysis of the immunopurified receptor by SDS-PAGE autoradiography revealed phosphorylated components. Sometimes, a single, major labeled species of about $60 \mathrm{kDa}$ was obtained, accompanied by a small amount of labeled material distributed between 50 and $60 \mathrm{kDa}$. More often, 2 major species were resolved (Fig. 1A). Combining the results from a number of such experiments yielded $M_{\mathrm{r}} \mathrm{s}$ of $49.8 \pm 0.2$ (mean $\pm \mathrm{SE}, n$ $=10$; "50 kDa") and $57.5 \pm 0.5 \mathrm{kDa}(n=14$; " $58 \mathrm{kDa}$ ") for the 2 labeled species. Both were specifically immunoabsorbed by mAb-35 Sepharose as expected for AChR-associated components: they were depleted from the preparation by passage over the immunoaffinity resin, and they were prevented from binding to the immunoaffinity resin by an excess of free $\mathrm{mAb}$ 35 but not by an excess of free rat IgG (Fig. $1 A$ ). ${ }^{32} \mathrm{P}_{i}$ incorporation into both the 50 - and $58-\mathrm{kDa}$ species was increased when the neurons were incubated with a membrane-permeant analog of cAMP, 8-Br-cAMP, together with the phosphodiesterase inhibitor IBMX (Fig. 1A). The 6-hr incubation with ${ }^{32} \mathrm{P}$-orthophosphate appeared sufficient to equilibrate the ATP pool because increasing the incubation to $18 \mathrm{hr}$ (with and without $8-\mathrm{Br}$ cAMP and IBMX for the last $6 \mathrm{hr}$ ) produced a pattern and extent of labeling similar to that shown in Figure $1 A$.

\section{Phosphorylation of $\alpha 3$ gene products}

To correlate the phosphorylated species with AChR subunits, ${ }^{32} \mathrm{P}$-labeled AChRs were purified with 2 rounds of immunoaffinity absorption and compared by SDS-PAGE with ${ }^{125}$ I-labeled AChRs purified in parallel from sister cultures. Previously, ${ }^{125} \mathrm{I}-$ labeled components of 49,52 , and $60 \mathrm{kDa}$ were identified in purified preparations of ciliary ganglion AChRs (Halvorsen and Berg, 1990). In the present experiments, 2 major ${ }^{125} \mathrm{I}$-labeled species were obtained (Fig. $1 B$ ). Combining the results of 9 separate determinations yielded $M_{\mathrm{r}} \mathrm{s}$ of $51.3 \pm 0.2$ and $58.9 \pm$ $0.3 \mathrm{kDa}$ for the 2 species. The amount of the smaller species varied considerably among experiments and was often greater than the amount of the larger. The method of receptor purification used here apparently permitted some degradation of the larger species, converting it to smaller material that probably prevented resolution of the $49-$ and $52-\mathrm{kDa}$ components distinguished previously (Halvorsen and Berg, 1990; see below and

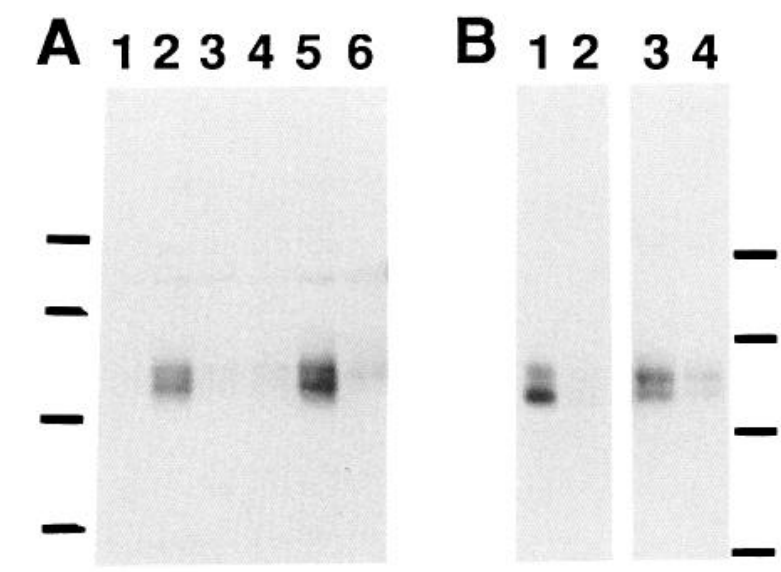

Figure 1. cAMP-dependent phosphorylation of AChR subunits. A, SDS-PAGE autoradiography of ${ }^{32} \mathrm{P}$-labeled $\mathrm{AChRs}$ immunopurified from chick ciliary ganglion cells in culture. Phosphorylation was carried out by incubating the neurons in ${ }^{32} \mathrm{P}$-orthophosphate either without (lanes $1-3$ ) or with 8-Br-cAMP and IBMX (lanes 4-6). Lanes 1 and 4, "Depleted extract" obtained by carrying out a mock purification with material that remained unbound after the initial AChR absorption to the immunoaffinity resin. Lanes 2 and 5, Purified AChRs. Lanes 3 and 6 , "Nonspecific" material obtained by using free mAb 35 to block immunoaffinity purification of the receptor. Each lane contained about 14 fmol AChR, assuming $2 \mathrm{mAb}-35$ sites per receptor (Halvorsen and Berg, 1987). Phosphorylated species of 50 and $58 \mathrm{kDa}$ are apparent, and their relative intensities were increased by incubating the cells with $8-\mathrm{Br}$ cAMP and IBMX. $B$, An SDS-PAGE comparison of ${ }^{125} \mathrm{I}-$ and ${ }^{32} \mathrm{P}$-labeled AChRs obtained by 2 rounds of immunoaffinity purification. Lanes 1 and 2, ${ }^{125}$ I-labeled material. Lanes 3 and 4, ${ }^{32}$ P-labeled material. Immunopurified AChR, lanes 1 and 3; "nonspecific" material obtained as described above, lanes 2 and 4 . The 2 phosphorylated species migrate in a manner similar to but not identical with the 2 radioiodinated species. Molecular weight markers used were phosphorylase B $(97 \mathrm{kDa})$, BSA (68 kDa), ovalbumin (43 kDa), and carbonic anhydrase (29 kDa).

Discussion). In most experiments, the 2 major ${ }^{32} \mathrm{P}$-labeled species comigrated with the 2 major ${ }^{125} \mathrm{I}$-labeled species (Fig. $1 B$ ). In some cases, however, one or both of the ${ }^{32} \mathrm{P}$-labeled species migrated slightly ahead of the corresponding ${ }^{125} \mathrm{I}$-labeled species. This, together with the possibility of subunit degradation described above, motivated additional efforts to identify the ${ }^{32} \mathrm{P}$ labeled components.

Previously, an antiserum generated against an $\alpha 3$ fusion protein was used to obtain evidence that the $60-\mathrm{kDa}$ AChR component from ciliary ganglia was an $\alpha 3$ gene product (Halvorsen and Berg, 1990). The $\alpha 3$ region of the fusion gene encoded a putative cytoplasmic domain of the protein that was relatively unique among $\mathrm{AChR}$ subunits. Immunoprecipitation experiments with solubilized AChRs were consistent with the antiserum being specific for receptors containing the $\alpha 3$ gene product (Schoepfer et al., 1989). With isolated ganglionic components, the antiserum specifically immunoprecipitated the $60-\mathrm{kDa}$ species and crossreacted very little, if at all, with either the 49- or 52-kDa components (Halvorsen and Berg, 1990). The same antiserum was used here to determine whether either or both of the ${ }^{32} \mathrm{P}$-labeled species was likely to represent an $\alpha 3$ gene product. ${ }^{32} \mathrm{P}$-labeled $\mathrm{AChRs}$ were obtained by incubating cells in ${ }^{32} \mathrm{P}$-orthophosphate together with 8 -Br-cAMP and IBMX, then immunopurifying the receptors and subjecting them to SDS-PAGE. Both the 49-53-kDa and the 56-60-kDa regions of the gel were divided into 2 slices each. Each of the 4 slices was individually eluted, and the resulting material was reacted with the anti- $\alpha 3$ antiserum. SDS-PAGE autoradiography indi- 
SLICE:

SLICE:

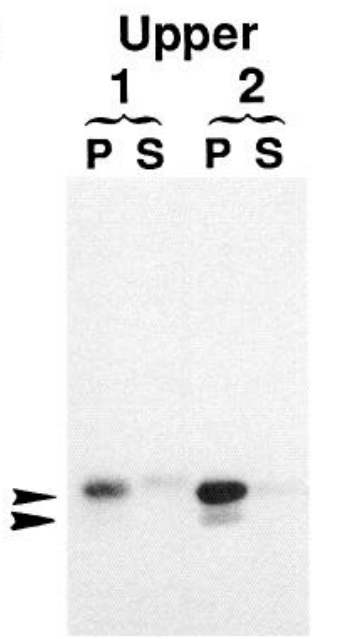

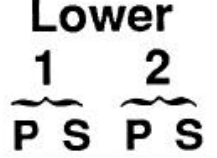

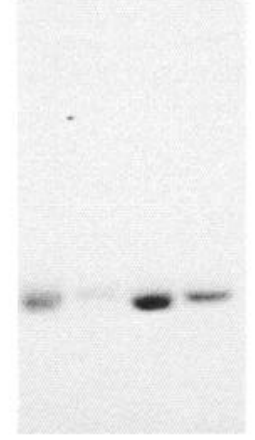

Figure 2. Immunoprecipitation of phosphorylated AChR components using antiserum to $\alpha 3$ fusion protein. ${ }^{32} \mathrm{P}$-labeled $\mathrm{AChR}$ components were separated by SDS-PAGE of receptor purified with one round of immunoaffinity absorption (as in Fig. $1 A$, lane 5). The 56-60-kDa section of the gel was cut out as 2 adjacent slices, with the first slice (Upper, 1) representing the top half of the section and the second slice (Upper, 2 ), the bottom half. Similarly, the $49-53-\mathrm{kDa}$ section was cut out as 2 adjacent slices representing the top and bottom halves of the section (Lower, 1 and 2, respectively). Material from each of the 4 slices was eluted and individually subjected to immunoprecipitation by an anti$\alpha 3$ antiserum absorbed to Staphylococcus aureus cells. The immunopreciptates and remaining supernatant fractions were analyzed by SDSPAGE autoradiography. Lane pairs show the immunoprecipitate $(P)$ and the corresponding material left in solution $(S)$ for each slice eluate. Arrowheads: upper, $58 \mathrm{kDa}$; lower, $51 \mathrm{kDa}$. Most of the ${ }^{32} \mathrm{P}$-labeled material both in the $56-60-\mathrm{kDa}$ and in the $49-53-\mathrm{kDa}$ regions was efficiently immunoprecipitated by the antiserum, consistent with the phosphorylated species being derived from $\alpha 3$ subunits. Some material in the 49-53-kDa range remained in solution after the immunoprecipitation (Lower, $2 S$ ), representing either contaminating phosphorylated material or limited phosphorylation of a non- $\alpha 3$ AChR subunit.

cated that a large proportion of the labeled material from all 4 slices was efficiently immunoprecipitated with the antiserum (Fig. 2). Apparently, most of the labeled material present both as 50 - and $58-\mathrm{kDa}$ species represents $\alpha 3$ gene products (or the products of closely related AChR $\alpha$ genes). A small amount of labeled material in the lower size range remained in solution after the immunoprecipitation (Fig. 2, Lower, 2S) and presumably represents either contaminating material or a small amount of phosphorylation on another AChR subunit. The fact that some labeled material from the $56-60-\mathrm{kDa}$ range migrated as smaller material after immunoprecipitation (Fig. 2, Upper, 2P) suggests that some degradation occurs under these conditions.

To confirm the specificity of the anti- $\alpha 3$ antiserum in the present experiments, immunoprecipitations were carried out with isolated ${ }^{125} \mathrm{I}$-labeled AChR components. The labeled components were obtained by SDS-PAGE. Gel regions corresponding to the $49-53-\mathrm{kDa}$ and the $56-60-\mathrm{kDa}$ size ranges were eluted separately, and the eluted material was repeatedly absorbed with anti- $\alpha 3$ antiserum. The large species was efficiently brought down with the first immunoprecipitation (Fig. 3, Upper, $P_{1}$ ), as expected for an $\alpha 3$ subunit. Again, finding that some of the immunoprecipitated large species migrated as a smaller species of about $51 \mathrm{kDa}$ when reanalyzed by SDS-PAGE indicates that it can be partially degraded during handling. In contrast, the antiserum immunoprecipitated only a little of the original ${ }^{125}$ I-la-
Figure 3. Immunoprecipitation of radioiodinated AChR components using antiserum to $\alpha 3$ fusion protein. ${ }^{125}$ I-labeled $\mathrm{AChR}$ components were separated by SDS-PAGE performed on receptor purified with 2 rounds of immunoaffinity absorption (as in Fig. 1B, lane 1). Gel regions containing material of $56-60 \mathrm{kDa}$ (Upper) and 49-53 kDa (Lower) were cut out and eluted separately. The eluted material was sequentially immunoprecipitated 3 times with anti- $\alpha 3$ antiserum absorbed to Staphylococcus aureus cells in each case. The immunoprecipitates $\left(P_{f}-P_{3}\right)$ and corresponding material remaining in solution $(S)$ were analyzed by SDSPAGE autoradiography. Arrowheads: upper, $59 \mathrm{kDa}$; lower, $51 \mathrm{kDa}$. Most of the large material was efficiently immunoprecipitated by the antiserum (Upper, $\left.P_{t}\right)$, as expected for $\alpha 3$ subunits. Some of it migrated as a smaller species when rerun, indicating that degradation occurred during handling. Only a small part of the original small species was brought down in the first immunoprecipitation (Lower, $\left.P_{l}\right)$ and none subsequently (Lower, $P_{2}$ and $P_{3}$ ), indicating that while a small part of it probably derived from an $\alpha 3$ gene product, most of it represented a different AChR subunit.

beled material migrating at $51 \mathrm{kDa}$, despite repeated attempts (Fig. 3, Lower, $\mathrm{P}_{1}-\mathrm{P}_{3}$ ). This latter result indicates that much of the original ${ }^{125}{ }^{1}$-labeled $51-\mathrm{kDa}$ material did not derive from the $\alpha 3$ gene. Comparing the immunoprecipitations of ${ }^{32} \mathrm{P}-\mathrm{la}-$ beled and ${ }^{125} \mathrm{I}$-labeled material suggests that the large species is an $\alpha 3$ gene product and that it can be phosphorylated. In addition, as a result either of degradation or of cellular processing, some $\alpha 3$ gene product migrates as a smaller species. The smaller species can also be phosphorylated, and it overlaps during SDSPAGE with other components that receive little, if any, phosphorylation themselves.

If this interpretation is correct, the ${ }^{125} \mathrm{I}$-labeled material immunoprecipitated from the $49-53-\mathrm{kDa}$ range of the gel should be similar in composition to the material immunoprecipitated from the 56-60-kDa range and should differ from the 49-53$\mathrm{kDa}$ material remaining in solution. This follows from the observation that all 3 components originally identified in $\mathrm{AChR}$ preparations from ciliary ganglia had unique peptide maps when analyzed by 1-dimensional SDS-PAGE after limited proteolysis (Halvorsen and Berg, 1990). To test this prediction, anti- $\alpha 3 \mathrm{im}$ munoprecipitates and supernatant fractions were recovered from an experiment such as that described in Figure 3 and were subjected to limited digestion with Staphylococcus V8 protease followed by SDS-PAGE autoradiography. It is clear that the labeled peptide patterns of the 2 immunoprecipitates are essentially identical and that they differ substantially from the pattern obtained from the labeled material that remained in solution 


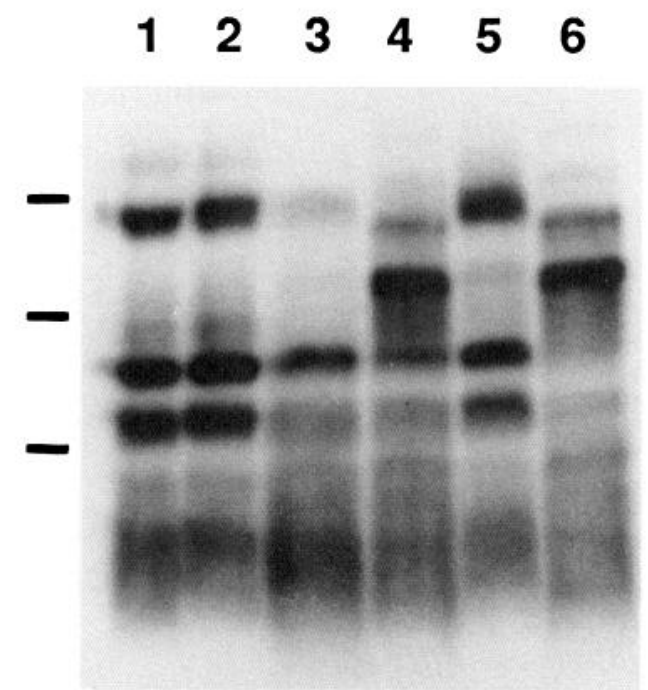

Figure 4. Peptide mapping of ${ }^{125}$ I-labeled AChR components immunoprecipitated by anti- $\alpha 3$ antiserum. ${ }^{125}$ I-labeled immunoprecipitates and corresponding soluble material obtained from the 56-60-kDa range and from the 49-53-kDa range of a gel were prepared as described in Figure 3 and subjected to limited digestion with Staphylococcus V8 protease followed by SDS-PAGE autoradiography. Lanes 1-3, "56-60"$\mathrm{kDa}$ material before reaction with antiserum (lane 1), immunoprecipitated by the antiserum (lane 2), and remaining in solution after the immunoprecipitation (lane 3). Lanes 4-6, "49-53"-kDa material before reaction with the antiserum (lane 4 ), immunoprecipitated by the antiserum (lane 5), and remaining in solution after the immunoprecipitation (lane 6). Equivalent amounts of radioactivity were applied to the lanes. Lanes 2 and 5 contain the same major peptides, indicating that very similar material was immunoprecipitated in the 2 cases. The peptide analysis further confirms the identity between the immunoprecipitated material and the major species present in the $56-50-\mathrm{kDa}$ material while showing the dissimilarity between the immunoprecipitated material and the major species present in the 49-53-kDa material. Molecular weight markers (prestained, Bethesda Research Labs) shown are ovalbumin (migrating as $42 \mathrm{kDa}$ ), carbonic anhydrase (migrating as $26 \mathrm{kDa}$ ), and $\alpha$-lactoglobulin (migrating as $18 \mathrm{kDa}$ ).

(Fig. 4). Similar conclusions emerged when papain was used for the digestions instead of V8 protease (data not shown). These results further support the contention that the 50 - and $58-\mathrm{kDa}$ ${ }^{32} \mathrm{P}$-labeled species derive from the same gene, presumably the $\alpha 3$ gene, and that they differ from other components present in the $49-53-\mathrm{kDa}$ region of the gel.

\section{Specificity and time course of CAMP-dependent phosphorylation}

The increased phosphorylation observed in the presence of $8-\mathrm{Br}$ cAMP and IBMX (Fig. 1A) was specific for a cAMP-dependent process. Other membrane-permeant cAMP analogs were able to substitute for 8-Br-cAMP in producing the effect. Neither AMP nor a membrane-permeant analog of cGMP was able to increase the labeling of either species. The results were quantitated by using scintillation counting to measure the amount of radioactivity present in gel slices containing the isolated species after SDS-PAGE. Nonspecific radioactivity present in equivalent gel slices from lanes lacking $\mathrm{AChRs}$ was subtracted in each case. Radioactivity associated with the 50- and 58-kDa species was combined to illustrate the total phosphorylation associated with putative $\alpha 3$ subunits in the receptor (Fig. 5).

An unusual feature in the regulation of neuronal ACh sensitivity by cAMP analogs is the relatively long time required

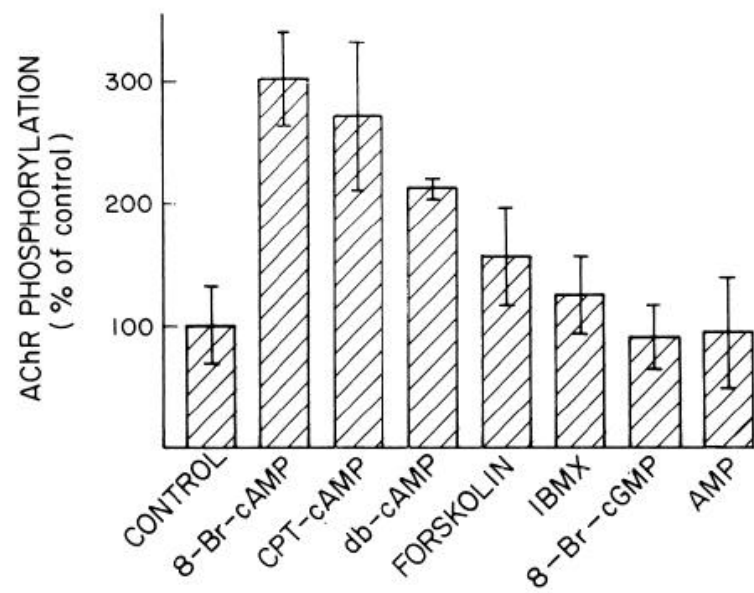

Figure 5. Dependence of AChR phosphorylation on cAMP analogs. Cells were incubated with ${ }^{32} \mathrm{P}$-orthophosphate and the indicated compounds for $6 \mathrm{hr}$ (except for forskolin, which was present only for the last $30 \mathrm{~min}$ ). All test compounds were supplied at $2 \mathrm{~mm}$, except forskolin $(10 \mu \mathrm{M})$. AChRs were purified from the cells and analyzed by SDSPAGE autoradiography. Radioactivity associated with individual bands was quantitated by cutting appropriate slices from the dried gel and submitting them to scintillation counting. Corrections were made for nonspecific radioactivity and quenching (see Materials and Methods). Data represent the sum of values obtained for the $50-$ and $58-\mathrm{kDa}$ phosphorylated species and are expressed as a percent (mean $\pm \mathrm{SE}$ of 3 experiments) of that obtained in the absence of the added test compounds. All 3 cAMP analogs caused a significant increase in receptor phosphorylation; forskolin had a marginal effect, while the cGMP analog and AMP had no effect. CPT-cAMP, chlorophenylthio-cAMP; db-cAMP, dibutryl-cAMP.

for an observable effect (Margiotta et al., 1987a). To determine whether the cAMP-dependent phosphorylation of AChR $\alpha 3$ subunits observed here was a candidate for the mechanism by which cAMP analogs increase the $\mathrm{ACh}$ response, we compared the time courses of the 2 effects. Ciliary ganglion neurons in culture were incubated with ${ }^{32} \mathrm{P}$-orthophosphate for the standard 6-hr period. 8-Br-cAMP and IBMX were added at various times during the incubation to achieve drug exposures that ranged from 0 to $6 \mathrm{hr}$, always terminating with the end of the phosphorylation period. AChRs were then immunopurified and quantitated by SDS-PAGE and scintillation counting to determine the amount of ${ }^{32} \mathrm{P}$-labeling associated with the receptors. Radioactivity in gel slices from control lanes lacking AChRs was subtracted in each case to yield specific labeling. No increase in AChR phosphorylation was observed during the first $30 \mathrm{~min}$ of exposure to the cAMP analog. Receptor phosphorylation subsequently increased, by $6 \mathrm{hr}$ reaching a level 2- to 3-fold that observed for AChRs from cells not exposed to the cAMP analog. The results were the same whether the levels of labeling associated with the 50- and 58-kDa components were analyzed separately (data not shown) or together (Fig. 6). A similar lag period and relative increase were observed for the effects of cAMP analogs on the $\mathrm{ACh}$ response. Again, no increase was detected during the first $30 \mathrm{~min}$. After $6 \mathrm{hr}$ incubation with 8 -Br-cAMP and IBMX, the mean ACh response was 2- to 3-fold that observed for control cells (Fig. 6). The amount of variation observed at intermediate times (e.g., $1 \mathrm{hr}$ ) prevented a more detailed comparison of the time courses.

\section{Stoichiometry of AChR phosphorylation}

The AChR phosphorylation caused by cAMP analogs represented an increase in the extent of receptor phosphorylation 


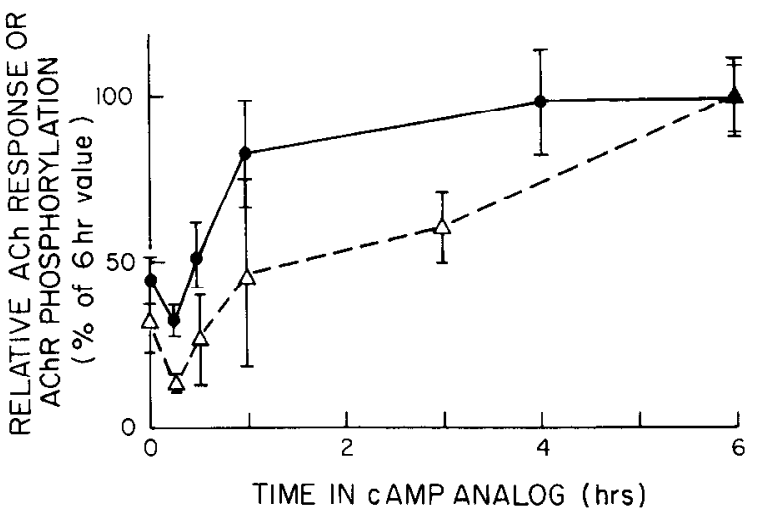

Figure 6. Time course of cAMP-dependent effects on ciliary ganglion AChRs. Cells were incubated with either ${ }^{32} \mathrm{P}$-orthophosphate or unlabeled phosphate for $6 \mathrm{hr}$. At appropriate times during the incubation, the medium was supplemented with $2 \mathrm{mM} 8-\mathrm{Br}$-cAMP and $1 \mathrm{mM} \mathrm{IBMX}$ to achieve the indicated times of exposure by the end of the labeling period. For ${ }^{32} \mathrm{P}$-labeled cultures (60-mm dishes), AChRs were purified, subjected to SDS-PAGE autoradiography, and quantitated for radioactivity as described in Figure 5 (open triangles). For unlabeled cultures (35-mm dishes), intracellular recording was used to measure neuronal ACh responses (solid circles). Phosphorylation results represent the mean \pm SE of 3-6 cultures per time point combined from 3 separate experiments and are expressed as a percent of the 6-hr value. Physiological results represent the mean \pm SE of 12-28 neurons per time point combined from 4 separate experiments and are similarly expressed.

rather than an increase in the total number of receptors. This was shown by incubating cultures with and without 8-Br-cAMP and IBMX for $6 \mathrm{hr}$, then assaying the total number of $\Lambda \mathrm{ChRs}$ present in detergent extracts prepared from the cultures as previously described (Stollberg and Berg, 1987). No differences were detected in the number of total AChRs per culture with and without the drugs (Table 1 ). Treating the cells with $8-\mathrm{Br}$ cAMP and IBMX for $6 \mathrm{hr}$ also had no effect on the amount or specific activity of $\gamma^{32} \mathrm{P}-\mathrm{ATP}$ in the cells (Table 1).

The stoichiometry of $\mathrm{AChR}$ phosphorylation was calculated by quantitating the amount of ${ }^{32} \mathrm{P}$ radioactivity associated with receptor subunits after SDS-PAGE, determining the number of AChRs applied to the gel, and measuring the specific activity of the intracellular $\gamma-{ }^{32} \mathrm{P}-\mathrm{ATP}$ pool at the time of receptor labeling. The amount of $\mathrm{AChR}$ measured in the initial culture extract, using the DEAE-cellulose assay (Smith et al., 1985), was corrected for the efficiency of AChR absorption to $\mathrm{mAb}-35$ Sepharose (around 90\%) and the efficiency of acid elution from the resin (around 50\%). Similar efficiencies were obtained for AChRs from cultures incubated with and without 8-Br-cAMP and IBMX. For purposes of calculating the moles of AChR present, it was assumed that $2 \mathrm{mAb}-35$ molecules bind to a single AChR. While it is likely that the number of $\mathrm{mAb}-35$ binding sites on the receptor is greater than 1 (Halvorsen and Berg, 1987), the exact number is unknown. The amount of ${ }^{32} \mathrm{P}$ labeling associated with receptor subunits was determined by carrying out scintillation counting on gel slices. A correction of $18 \%$ was made for the lower efficiency of scintillation counting of ${ }^{32} \mathrm{P}$ radioactivity in dried gel samples relative to aqueous samples. Dividing the values by the specific activity of the $\gamma-{ }^{32} \mathrm{P}-$ ATP in the cells and by the amount of receptor in the sample provided estimates for the stoichiometry of AChR phosphorylation. In the absence of cAMP analogs, the receptors acquired about $0.3 \mathrm{~mol}$ labeled phosphate per mol receptor during a 6 -hr
Table 1. Stoichiometry of cAMP-dependent AChR phosphorylation

\begin{tabular}{llll} 
Cultures & $\begin{array}{l}\text { Total AChRs } \\
\text { (fmol/culture) }\end{array}$ & $\begin{array}{l}\text { Specific } \\
\text { activity of } \\
(\mathrm{cpm} / \mathrm{fmol})\end{array}$ & $\begin{array}{l}\text { Stoichiometry of } \\
\text { phosphorylation } \\
\text { (mol } \text { P }_{i} / \mathrm{mol}\end{array}$ \\
\hline AChR)
\end{tabular}

The amount of ${ }^{32} \mathrm{P}$ associated with AChRs was determined as described in Figure 5 . The total number of $\mathrm{AChRs}$ was determined by measuring ${ }^{125} \mathrm{I}-\mathrm{mAb}-35$ binding sites in detergent extracts prepared from sister cultures (Stollberg and Berg, 1987). ATP concentrations were determined for culture extracts using a luciferin-luciferase assay (Karl and Holm-Hansen, 1976). Specific activities of $\gamma-{ }^{32} \mathrm{P}$-ATP were then determined by measuring the amount of ${ }^{32} \mathrm{P}$ labeling associated with the $\gamma$ position of ATP in perchloric acid extracts of the cultures as previously described (England and Walsh, 1976). Values indicate the mean \pm SEM for the number of observations indicated in parentheses.

incubation with ${ }^{32} \mathrm{P}$-orthophosphate (Table 1). Including 8-BrCAMP and IBMX in the incubation increased the amount of phosphorylation to about $0.8 \mathrm{~mol}$ per mol receptor, a 2.7 -fold increase (Table 1).

\section{Discussion}

The major findings presented here are that chick ciliary ganglion AChRs can be phosphorylated in situ in a cAMP-dependent manner. The phosphorylation follows a relatively slow time course and occurs predominantly on ligand-binding $\alpha$ subunits. It differs in both these latter respects from the rapid cAMPdependent phosphorylation of electric organ AChRs that occurs on $\gamma$ and $\delta$ subunits (Huganir et al., 1986) and that of muscle AChRs that occurs on $\delta$ subunits (Miles et al., 1987; Smith et al., 1987).

Phosphorylated species of 50 and $58 \mathrm{kDa}$ were obtained from ciliary ganglion AChRs. Both appear to represent $\alpha 3$ gene products because both can be efficiently immunoprecipitated by an antiserum raised against an $\alpha 3$ fusion protein. Evidence presented here and elsewhere (Schoepfer et al., 1989; Halvorsen and Berg, 1990) is consistent with the anti- $\alpha 3$ antiserum being specific for $\alpha 3$ gene products, and substantial amounts of $\alpha 3$ mRNA are expressed in ciliary ganglion neurons (Boyd et al,, 1988). Nonetheless, we cannot exclude the possibility that some of the immunoprecipitated material derives from a closely related AChR gene not yet identified in the ganglion. In any case, the contention that the 2 phosphorylated species are encoded by the same gene is strongly supported by the finding that peptide analysis of the corresponding ${ }^{125}$ I-labeled immunoprecipitates formed from the $50-$ and $58-\mathrm{kDa}$ samples reveals equivalent patterns. Affinity-labeling experiments previously identified an AChR subunit of about $59 \mathrm{kDa}$ likely to be associated with the ligand-binding site, as expected for an $\alpha$-type AChR subunit (Halvorsen and Berg, 1987). Sometimes, a smaller component was also revealed by the affinity-labeling procedure, possibly corresponding to the smaller species detected here by phosphorylation.

Previous studies on purified AChRs from chick ciliary ganglia implicated only a large species as being an $\alpha 3$ subunit (Halvorsen and Berg, 1990). The difference between that work and the present one is likely to result from the different methods of receptor isolation. To maximize $\mathrm{AChR}$ recoveries here for the phosphorylation analysis, it proved necessary to isolate AChRs directly from whole culture extracts rather than from a particulate fraction, as done previously (Halvorsen and Berg, 1990). 
Brief exposure to proteases in the whole extract may permit greater cleavage of subunits in solubilized receptors. Conversion of some $\alpha 3$ subunits to a smaller species during receptor purification would account for the appearance of $2{ }^{32} \mathrm{P}$-labeled AChR components that can be immunoprecipitated by anti- $\alpha 3$ antiserum. That such degradation can occur is illustrated by the observation that SDS-PAGE of isolated ${ }^{125} \mathrm{I}$-labeled $59-\mathrm{kDa}$ components, after incubating with antiserum, yields material of $51 \mathrm{kDa}$ in addition to the original component of $59 \mathrm{kDa}$. Degradation of some $\alpha 3$ subunits to a smaller species during purification could also explain why the amount of ${ }^{125}$ [-labeled AChR material migrating at about $51 \mathrm{kDa}$ was variable and often exceeded substantially the amount of ${ }^{125}$ I-labeled AChR material at $59 \mathrm{kDa}$. The size of the degraded species $(50-51 \mathrm{kDa})$ would tend to obscure SDS-PAGE resolution of the 49- and 52$\mathrm{kDa}$ components previously identified in AChR preparations (Halvorsen and Berg, 1990). It is, of course, possible that production of $2 \alpha 3$ species occurs intracellularly under certain conditions as part of normal processing of $\alpha 3$ gene products.

The chicken AChR $\alpha 3$ gene does not appear to encode a known consensus sequence for phosphorylation by cAMP-dependent protein kinase (Ner et al., 1988). It does, however, contain several candidate sequences in putative cytoplasmic domains. Some of these have been shown to permit phosphorylation by the kinase at a reduced rate in other proteins (Huang et al., 1974; Kemp et al., 1975; Rohrkasten et al., 1988). Examples include the sequences with serines at positions 329 and 391. The fact that the sequences are not optimal substrates for the kinase may account for the slow rate of AChR phosphorylation observed in situ. Alternative explanations for the slow rate may include restricted access to the phosphorylation site or requirements for intervening events. For example, cAMP-dependent protein kinase may not phosphorylate the receptor directly but instead may activate other kinases that carry out the phosphorylation. It is unlikely that the rate-limiting step is entry of cAMP analogs into the neurons. The analogs are designed to enter cells quickly and, in the case of muscle, clearly do so, as evidenced by their rapid effects on phosphorylation of muscle AChR $\delta$ subunits. Interestingly, muscle AChR $\alpha 1$ subunits undergo a slow cAMPdependent phosphorylation of unknown function as described here for putative $\alpha 3$ subunits (Smith et al., 1987, 1989).

No sequence information is available yet for the 49- and 52$\mathrm{kDa}$ components previously identified in $\mathrm{AChR}$ preparations. Neither should be immunoprecipitated by the anti- $\alpha 3$ antiserum (Halvorsen and Berg, 1990). The small amount of ${ }^{32} \mathrm{P}$-labeled material at 50-51 kDa that resists immunoprecipitation by the antiserum could represent a low level of phosphorylation on either of these 2 components.

The physiological significance of AChR $\alpha$ subunit phosphorylation is unknown. A cAMP-dependent process has been shown to increase the rate of agonist-induced desensitization observed for chick ciliary ganglion AChRs (Marigotta et al., 1987a). In the case of electric organ $\mathrm{AChRs}$, however, the rate of receptor desensitization is increased by cAMP-dependent phosphorylation of the $\gamma$ and $\delta$ subunits (Huganir et al., 1986). If ciliary ganglion AChRs behave similarly, one might expect the effect to be mediated by cAMP-dependent phosphorylation of some other subunit, for example, the 49- or 52-kDa components or an AChR non- $\alpha$ subunit yet to be identified because of proteolysis during isolation.

A second effect of cAMP on ciliary ganglion AChRs is an increase in the $\mathrm{ACh}$ response thought to occur by a cAMP- dependent conversion of receptors from a "silent" state to a "functionally available" one (Margiotta et al., 1987a; Margiotta and Gurantz, 1989). "Silent" in this case signifies a receptor state that does not generate a detectable change in membrane conductance when confronted with agonist under standard recording conditions. The cAMP-dependent phosphorylation of ciliary ganglion AChRs described here displays the same initial lag and subsequent relative increase following exposure of the cells to cAMP analogs as does the cAMP-dependent increase in ACh response. It is unlikely, however, that there is a simple 1:1 correspondence between the phosphorylation and receptor functionality. At a time when $0.8 \mathrm{~mol}$ phosphate have been incorporated per mol receptor, only a small fraction of the receptors appears to be functionally available (Marigotta et al., 1987a). Any of several explanations may account for the discrepancy. Not all of the phosphates may be on relevant sites. (The basal level of phosphorylation, i.e., $0.3 \mathrm{~mol}$ phosphate $/ \mathrm{mol}$ receptor, may not even be cAMP-dependent.) More than one phosphate may be required per receptor. Phosphorylation may serve only to shift the equilibrium between silent and functionally available states, increasing dwell time in the latter rather than provoking an all-or-none conversion.

A third possible role for phosphorylation of ciliary ganglion AChRs is that it may regulate intracellular events such as receptor assembly and transport. Because whole culture extracts were used in the present experiments to obtain sufficient material, much of the isolated receptor represented AChRs from an intracellular pool (Stollberg and Berg, 1987). It was not possible to determine the relative contributions of surface versus intracellular receptors to the observed phosphorylation. Intracellular AChR species in skeletal muscle may have substantial levels of phosphorylation as has been reported for the $\delta$ subunit (Ross et al., 1987). If phosphorylation of $\alpha 3$ subunits in ciliary ganglion neurons is confined to intracellular receptor species, it would be unlikely to influence AChR function, except perhaps by controlling the types of species available for transport to the cell surface.

Each of the 3 potential physiological effects could have important consequences for signal detection by ciliary ganglion neurons. Exerting such effects through a cAMP-dependent phosphorylation of AChRs would provide a mechanism by which cell-cell interactions could influence synaptic modulation in the ganglion over the long term.

\section{References}

Albuquerque EX, Deshpande SS, Aracava Y, Alkondon M, Daly JW (1986) A possible involvement of cyclic AMP in the expression of desensitization of the nicotinic acetylcholine receptor. FEBS Lett 199: 113-120.

Boyd, RT, Jacob MH, Couturier S, Ballivet M, Berg DK (1988) Expression and regulation of neuronal acetylcholine receptor mRNA in chick ciliary ganglia. Neuron 1:495-502.

Cleveland DW, Fischer SG, Kirschner MW, Laemmli UK (1977) Peptide mapping by limited proteolysis in sodium dodecyl sulfate and analysis by gel electrophoresis. J Biol Chem 252:1102-1106.

Downing JE, Role LW (1987) Activators of protein kinase C enhance acetylcholine receptor desensitization in sympathetic ganglion neurons. Proc Natl Acad Sci USA 84:7739-7743.

England PJ, Walsh DA (1976) A rapid method for the measurement of $\left[\gamma-{ }^{32} \mathrm{P}\right] \mathrm{ATP}$ specific radioactivity in tissue extracts and its application to the study of ${ }^{32} \mathrm{P}_{i}$ uptake in perfused rat heart. Anal Biochem 75:429-435.

Eusebi F, Molinaro M, Zani BM (1985) Agents that activate protein kinase $C$ reduce acetylcholine sensitivity in cultured myotubes. J Cell Biol 100:1339-1342. 
Halvorsen SW, Berg DK (1987) Affinity labeling of neuronal acetylcholine receptor subunits with an $\alpha$-neurotoxin that blocks receptor function. J Neurosci 7:2547-2555.

Halvorsen SW, Berg DK (1990) Subunit composition of nicotinic acetylcholine receptors from chick ciliary ganglia. J Neurosci 10:17111718.

Heuschneider G, Schwartz RD (1989) cAMP and forskolin decrease $\gamma$-aminobutyric acid-gated chloride flux in rat brain synaptoneurosomes. Proc Natl Acad Sci USA 86:2938-2942.

Higgins LS, Berg DK (1988) Cyclic AMP-dependent mechanism regulates acetylcholine receptor function on bovine adrenal chromaffin cells and discriminates between new and old receptors. J Cell Biol 107:1157-1165.

Hopfield JF, Tank DW, Greengard P, Huganir RL (1988) Functional modulation of the nicotinic acetylcholine receptor by tyrosine phosphorylation. Nature 336:677-680.

Huang TS, Bylund DB, Stull JT, Krebs EG (1974) The amino acid sequences of the phosphorylated sites in troponin-I from rabbit skeletal muscle. FEBS Lett 42:249-252.

Huganir RL, Delcour AH, Greengard P, Hess GP (1986) Phosphorylation of the nicotinic acetylcholine receptor regulates its rate of desensitization. Nature 321:774-776.

Kaczmarek LK, Levitan IB (1987) Neuromodulation: the biochemical control of neuronal excitability. New York: Oxford UP.

Karl DM, Holm-Hansen O (1976) Effects of luciferin concentration on the quantitative assay of ATP using crude luciferase preparations. Anal Biochem 75:100-112.

Kemp BE, Bylund DB, Huang T-S, Krebs EG (1975) Substrate specificity of the cyclic AMP-dependent protein kinase. Proc Natl Acad Sci USA 72:3448-3452.

Levitan IB (1988) Modulation of ion channels in neurons and other cells. Ann Rev Neurosci 11:119-136.

Margiotta JF, Gurantz D (1989) Changes in the number, function, and regulation of nicotinic acetylcholine receptors during neuronal development. Dev Biol 135:326-339.

Margiotta JF, Berg DK, Dionne VE (1987a) Cyclic AMP regulates the proportion of functional acetylcholine receptors on chicken ciliary ganglion neurons. Proc Natl Acad Sci USA 84:8155-8159.

Margiotta JF, Berg DK, Dionne VE (1987b) The properties and regulation of functional acetylcholine receptors on chick ciliary ganglion neurons. J Neurosci 7:3612-3622.

McEachern AE, Margiotta JF, Berg DK (1985) $\gamma$-aminobutyric acid receptors on chick ciliary ganglion neurons in vivo and in cell culture. J Neurosci 5:2690-2695.

McEachern AE, Jacob MH, Berg DK (1989) Differential effects of nerve transection on the ACh and GABA receptors of chick ciliary ganglion neurons. J Neurosci 9:3899-3907.
Middleton P, Jaramillo F, Schuetze SM (1986) Forskolin increases the rate of acetylcholine receptor desensitization at rat soleus endplates. Proc Natl Acad Sci USA 83:4967-4971.

Middleton P, Rubin LL, Schuetze SM (1988) Desensitization of acetylcholine receptors in rat myotubes is enhanced by agents that elevate intracellular cAMP. J Neurosci 8:3405-3412.

Miles K, Anthony DT, Rubin LL, Greengard P, Huganir RL (1987) Regulation of nicotinic acetylcholine receptor phosphorylation in rat myotubes by forskolin and cAMP. Proc Natl Acad Sci USA 84:65916595.

Nef P, Oneyser C, Alliod C, Couturier S, Ballivet M (1988) Genes expressed in the brain define three distinct neuronal nicotinic acetylcholine receptors. EMBO J 7:595-601.

Nishi R, Berg DK (1981) Two components from eye tissue that differentially stimulate the growth and development of ciliary ganglion neurons in cell culture. J Neurosci 1:505-513.

Rohrkasten A, Meyer HE, Nastainczyk W, Sieber M, Hofmann F (1988) cAMP-dependent protein kinase rapidly phosphorylates serine- 687 of the skeletal muscle receptor for calcium channel blockers. J Biol Chem 263:15325-15329.

Ross AF, Rapuano M, Schmidt JH, Prives JM (1987) Phosphorylation and assembly of nicotinic acetylcholine receptor subunits in cultured chick muscle cells. J Biol Chem 262:14640-14647.

Schoepfer R, Halvorsen SW, Conroy WG, Whiting P, Lindstrom J (1989) Antisera against an acetylcholine receptor $\alpha 3$ fusion protein bind to ganglionic but not to brain nicotinic acetylcholine receptors. FEBS Lett 257:393-399.

Smith MA, Margiotta JF, Berg DK (1983) Differential regulation of acetylcholine sensitivity and $\alpha$-bungarotoxin-binding sites on ciliary ganglion neurons in cell culture. J Neurosci 3:2395-2402.

Smith M, Stollberg J, Lindstrom JM, Berg DK (1985) Characterization of a component in chick ciliary ganglia that cross-reacts with monoclonal antibodies to muscle and electric organ acetylcholine receptor. J Neurosci 5:2726-2731.

Smith MM, Merlie JP, Lawrence JC Jr (1987) Regulation of phosphorylation of nicotinic acetylcholine receptors in mouse $\mathrm{BC} 3 \mathrm{H} 1$ myocytes. Proc Natl Acad Sci USA 84:6601-6605.

Smith MM, Merlie JP, Lawrence JC Jr (1989) $\mathrm{Ca}^{2+}$-dependent and cAMP-dependent control of nicotinic acetylcholine receptor phosphorylation in muscle cells. J Biol Chem 264:12813-12819.

Stollberg J, Berg DK (1987) Neuronal acetylcholine receptors: fate of surface and internal pools in cell culture. J Neurosci 7:1809-1815.

Whiting P, Lindstrom J (1986) Purification and characterization of a nicotinic acetylcholine receptor from chick brain. Biochemistry 25 : 2082-2093. 